\title{
ПОЛИТИЧЕСКИЕ КОММУНИКАЦИИ
}

\author{
Карпов В.В.
}

\section{ПОАИТИЧЕСКИЕ КОММУНИКАЦИИ В СТРУКТУРЕ РЕГИОНААЬНОГО ПОАИТИЧЕСКОГО РR (на примере органов исполнитемьной вмасти Омской области)}

\begin{abstract}
Аннотация. Предметная область исследования охватывает процессы политической коммуникации на региональном пространстве в аспекте деятельности органов исполнительной власти. Аиамоговый характер коммуникаций обеспечивает достижение реализачии модели партисипаторной демократии. Поскольку наиболее полным и системным источником информачии о реализуемой органами власти стратегии политического $P R$ непосредственно выступают СМИ различной политической направленности, взглядов и воззрений, поэтому одной из наиболее репрезентативных методик оценки политического $P R$ на уровне региональной власти выступает контент-анализ. Предмет исследования находится в смежной области нескольких научных направлений, придавая последнему законченность и целостность процесса реализации авторского замысла. Ключевым методом исследования выступает контент-анализ, позволяющий посредством выделения ключевых категорий и единиц политического процесса, отраженных в СМИ, определить тенденции политического РR органов исполнительной власти субъекта РФ. В качестве самостолтельной группы методов использовались методы системного анализа и структурно-функииональный метод. Новизна исследования заключается в применении теоретико-прикладного метода контент-анализа для оценки деятельности органов исполнительной власти Омской области. Привлечение контент-анализа осуществмяется посредством выделения ключевых показателей, отражающих особенности восприятия СМИ деятельности органов власти. Используемые органами власти каналы политической коммуникации представляются недостаточными, поскольку свидетельствуют не о стратегическом, а о мобилизационном характере политики PR, реализуемой органами государственной власти Омской области.
\end{abstract}




\section{ПОАИТИКА И ОБЩЕСТВО • 5 (137) • 2016}

Аиалоговый характер коммуникации требует включения в государственное управление в качестве равноправных партнеров ряда политических акторов, предполагает процессы взаимной коммуникачии, истинного диалога, совместно выработанной договоренности. Аиалог означает, ито региональное правительство не просто доводит до граждан, их объединений уже выработанные решения и программы, добиваясь затем их поддержки, а привлекает объединения и граждан к участию в самом прочессе выработки и принятия решений. Причем, инициатором диалога не облзательно выступает правительство. Только в условиях равноправного диалога может идти речь о сетевой структуре политического PR. Взаимодействия властных и общественных структур в прочессах государственного управления, решения тех или иных конкретных задач, возможно, только на основе доверия, возникающего до и в процессе совместной деятельности между этими структурами, что в свою очередь предполагает открытость властных структур перед гражданами и их объединениями.

Ключевые слова: Политическал культура, Семантическая шкала, Политический имидж, Органь исполнительной власти, Политическая система, Политический прочесс, Контент-анализ, Политический PR, Политические коммуникачии, Политические акторы.

Abstract. The subject field of this research covers the processes of political communication on the regional space in the aspect of the work of executive authorities. The dialogue character of communications provides the achievement in realization of the participatory democratic model. Due to the fact that mass media of diverse political orientation, views, and ideas act as the most complete and systemic source of information about the political $P R$ strategy realized by the government authorities, thus one of the most representative methodologies of the assessment of political $P R$ on the level of regional level consists in content analysis. The subject of this research is situated in the intersection of several scientific disciplines, by adding to the latter completeness and integrity of the process of implementation of the author's idea. The scientific novelty consists in the introduction of a theoretical applied method of content analysis for the purpose of assessment of the work of Omsk Oblast representatives of executive branch. The attraction of content analysis is being realizes via determination of the main indexes that reflect the peculiarities of mass media perception of the work of the government authorities. The channels of political communication used by the government authorities are considered to be insufficient, because they testify to the mobilization character of the PR policy, rather than strategic. The dialogue character of communication requires inclusion of a number of political actors into the government administration as equal partners, as well as suggests the processes of mutual communication, true dialogue, and mutually developed agreement. It means that the regional government not just delivers the already developed solutions and programs to the citizens, but attracts them to participation in the entire process itself. And not necessarily the government acts as the initiator of dialogue. Only in the conditions of the equal dialogue we can talk about the network structure of the political PR.

Key words: Political actors, Political communications, Political culture, Semantic scale, Political image, Executive authorities, Political system, Political process, Content analysis, Political PR.

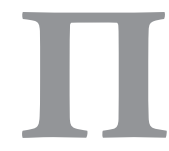
роцессы коммуникации пронизывают современное политическое пространство, придавая ему сетевой характер, и обеспечивая потребность участия всех субъектов в политическом процессе. Политическая активность субъектов политического процесса созАает условия Аля их взаимодействия, выработки согласованных решений и реализации механизмов сетевой координации ${ }^{1}$. По мнению социолога У. Шрама, коммуникации явмяются основным

\footnotetext{
Подробнее о месте политических коммуникаций в современном постдемократическом обществе: [Электронный ресурс]// [Режим доступа]: URL: http://www. politicalcommunication.org/ (Дата обращения: 21.09.2012).
} 
среАством структурирования социального пространства, «опредекяя статусные и познаватемьные характеристики его участников $>^{2}$. Процесс усложнения содержания, форм и способов выражения коммуникаций, характеризующий состояние современной помитической системы, актуамизирует проблему их концептуамьной оценки с позиций постнеклассического этапа развития научного знания ${ }^{3}$.

Процесс коммуникации вкмючает не только непосреАственную, но и опосреАованную переАачу информационных сигналов, поэтому он представляет собой разнонаправленный процесс, требующий его осмысления в рамках разАичных научных подходов. Аостаточно условно, исходя из содержатемьного аспекта коммуникаций, можно выАелить три концептуальных подхоАа.

Во-первых, классическая позитивистская парадигма первой половины ХІХв. (О. Конт, Г. Спенсер), признающая познавательный потенциа коммуникации как средства обеспечения взаимосвязи объектов, функционирования и развитие социума в ходе общественной практики. При этом результат коммуникативного взаимодействия зависел исключительно от мичностных и профессионацьных характеристик информатора - источника информации ${ }^{4}$. ОАнонаправ енный характер коммуникации не требовам намичия «обратной связи», ориентируясь на оценку качества избранного коммуникационного канала. Классическим примером использования Аанного концептуального подхода являются работы Г. Аассуэмиа 5 .

Во-вторых, неклассическая парадигма, нашеАшая свое выражение преимущественное в работах преАставителей феноменологии (Э. Гуссерль, Ю. Хабермас, М. Мерло-Понти). Процесс коммуникации оценивался в качестве особой формы общения, взаимодействия социальных субъектов, в условиях наличия разных возможностей и потребностей; творческого сотруА-

\footnotetext{
Schramm W. The nature of communications between humans. Urbana, 1972. - P. 38.

3 См. подр.: Voltmer K. Mass Media \& New Democracies. Routledge, 2012. - 240 p.

4 Подр. см.: Кривокора Е.И. Коммуникационные источники организационного развития / Е.И. Кривокора // Проблемы современной экономики. - № 3. - 2008. - С. 313 - 317. 5 Lasswell H. Propaganda technique in the World War. London, 1927. - P. 137.
}

ничества на основе равноправия и ценностных ориентаций. Аостаточно точно содержание коммуникации с позиций неклассической параАигмы выразим Ю. Хабермас: «... процессуально-созидательная, Аеятельностная форма общения, направценная на выработку новых цемей и творчество ${ }^{6}$. Основой Аиалога субъектов коммуникативного Аействия Аолжна стать взаимная интерпретация (взаимопонимание), т.е. согласие (consensus) ${ }^{7}$. Возможность Аостижения согласия связывалась с приобретением субъектами процесса универсальной коммуникативной компетенции через языковую переАачу смыслов ${ }^{8}$.

Продолжением теории коммуникативного Аействия Ю. Хабермаса стаха теория автопоэзиса Н. Аумана9. Смысловое значение коммуникации в политической системе определяется ее способностью выражаться и реализовываться в форме политических решений. Языковая общность по Ауману становится основой еАиного понимания смысла коммуникационных актов ${ }^{10}$. В отличие от Ю. Хабермаса Н. Ауман попытался выйти за пределы системного осмысления сущности и назначения коммуникации, признавая «невероятный» (а значит, принципиально непознаваемый) характер послеАней. Коммуникация невероятна, поскольку в процессе ее передачи выявляются три фактора: во-первых, автономность человеческого сознания не позвомяет ему понимать ту часть информации, которую подразумевает Аругой ее источник; во-вторых, коммуникация Аостигает большего числа АюАей, чем те, кто имеет отношение к конкретной ситуации; в-третьих, успех коммуникации - это восприятие получателем селективного соАержания информации ${ }^{11}$.

\footnotetext{
6 Хабермас Ю. Моральное сознание и коммуникативное действие / Ю. Хабермас. - СПб., 2000. - С. 176.

7 Хабермас Ю. Отношение к миру и рациональные аспекты действия в четырех социологических понятиях действия / Ю. Хабермас / Пер. с нем. Т. Тягуновой // Социологическое обозрение. - 2008. - Т. 7. - № 1. - С. 3 - 25.

8 См. подр.: Habermas J. What is universal pragmatics? // Communication and the evolution of society. N.Y.: Polity Press, 1984. - P. 1 - 68 .

9 См. подр.: Назарчук А.В. Теоретико-поэтические воззрения Никласа Лумана / А.В. Назарчук // Полис. - 2006. - № 3.

10 Луман Н. Власть / Н. Луман / Пер. с нем. А.Ю. Антоновского. М.: Праксис, 2001. - С.16.

11 Луман Н. Невероятность коммуникации / Н. Луман // Проблемы теоретической социологии / Ред. А.О. Бороноев. Вып. 3. СПб.: Изд-во СПбГУ, 2000. - С. 104.
} 
Таким образом, с позиций преАставитекей неклассического периода развития научного знания в основе коммуникативного поведения индивида межит процесс самопознания, понимания мира и смысла жизни, только в этом скучае возможно достижение коммуникативного консенсуса (взаимопонимания) между всеми субъектами политического процесса.

На пост неклассическом этапе развития науки второй половины XX в. была разработана новая научная парадигма, концептуальными основаниями которой поскужили теории самоорганизации (Г. Хакен, И. Пригожин) и теория политических сетей (Р. Родес, А.В. Сморгунов). Процесс коммуникации преАстает в качестве сложной коммуникативно-сетевой структуры, обладающей способностью к самоорганизации и основанной на принципе интерсубъективности (равенстве информационных ресурсов всех субъектов). Г. Хакен в ставшей кмассической работе «Информация и самоорганизация: макроскопический поАхоА к сложным системам» придает информации роль «решающего эмемента существования самой жизни», поскольку развитие Аюбой системы, ее выход из нейтрального, относительно стабильного состояния (аттрактора) становится возможным только при условии перманентного обмена информацией межАу различными частями системы ${ }^{12}$. Разнонаправменный характер покучаемой информации порожАает ее конкуренцию или кооперацию, результатом которой становится выработка общих Аля всех элементов системы параметров порядка. Информация, отнесенная к параметрам поряАка (синергетическая информация), в результате становится носителем «комлективного свойства» всей системы и причиной всех процессов в ней протекающих ${ }^{13}$.

На основе данных концепций разрабатываются отдельные теории, охватывающие размичные стороны процесса коммуникации. Так,

\footnotetext{
12 Хакен Г. Информация и самоорганизация: Макроскопический подход к сложным системам / Г. Хакен. - М.: Мир, 1991. - С. 45.

13 Под параметром порядка Г. Хакен подразумевает фундаментальную переменную системы, позволяющую дать единое описание процесса ее упорядочения. Основываясь на знании параметров порядка возможно посредством метода аналогии дать оценку системы в целом (Хакен Г. Информация... - С. 232).
}

одной из наиболее комплексных концепций стала структурно-функциональная модель политической системы, преАложенная М.Н. Грачевым, с точки зрения которой «политические коммуникации ... выступают в качестве компонента, обеспечивающего гомеостатическую устойчивость политической системы как целостного образования, находящегося в непрерывном взаимодействии с изменяющейся социальной средой ${ }^{14}$. Ключевые элементы политической системы оказываются, связаны меЖАу собой посреАством сложной сети политических коммуникаций, выступающих способом, средством существования и переАачи информации в рамках размичных модемей коммуникации ${ }^{15}$.

Весьма показательным Аля современного этапа развития политической мысли является подход Э. Тоффмера к оценке феномена политических коммуникаций. В условиях распространения информационных технологий, «самообучающихся систем» (нейронных сетей) коммуникативные возможности общества существенно возрастают. На смену интраразумным сетям, содержащим несколько коммуникативных каналов, в том числе и обратную связь, приходят экстраразумные сети, обладающие способностью самостоятельного перекодирования и изменения информации (с точки зрения ее объема и содержания) без участия источника и получателя последней ${ }^{16}$. В Аальнейшем роль и значение сетевых взаимодействий и коммуникации в процессе выработки нового знания помучимо концептуальную оценку в работах $\Lambda . B$. Сморгунова ${ }^{17}$, а также специалистов американской и английской школ публичной политики ${ }^{18}$.

\footnotetext{
14 Грачев М.Н. Политическая коммуникация: теоретикометодологический анализ: Автореф. дисс. докт. полит.н. М.: МГПУ, 2005 - С. 17.

15 Грачев М.Н. Политическая коммуникация: теоретические концепции, модели, векторы развития: Монография / М.Н. Грачев. - М.: Прометей, 2004. - С. 48.

16 Тоффлер Э. Метаморфозы власти / Пер. с анг. / Э. Тоффлер. - М.: ООО «Изд-во АСТ», 2003. - С. 145.

17 См. напр.: Сморгунов Л.В. Сети, знания, коммуникация / Л.В. Сморгунов // Демократия и управление: Информационный бюллетень исследовательского комитета РАПН по сравнительной политологии (СП-РАПН). - СПб: РАПН, 2006. - C. 5 - 14 .

18 Making Sense of Media \& Politics: Five Principles in Political Communication, by Gadi Wolfsfeld. New York: Routledge, 2011. - 160 p.; The News and Public Opinion: Media Effects on
} 
Разнообразие подходов к определению соАержания коммуникации, каналов ее переАачи и получения, структуры коммуникативного процесса обуславливает необходимость выработки комплексного определения, наиболее четко отражающего специфику его субъектов, канамов коммуникации и цемевых установок. Применительно к нашей статье мы остановимся на следующем определении: политическая коммуникация - это коммуникативная деятельность субъектов политического процесса, обусловленная целым рядом политически значимых оценок, конкретных ситуаций, коммуникативных сфер и норм общения, принятых в Аанном обществе. В результате политические коммуникации становятся неотъемлемой частью как политического процесса, так и социального пространства в цемом. Политический коммуникативный потенциал определяется нами в качестве совокупности способностей ключевых субъектов политического процесса находить консенсус посреАством использования разнообразных сетевых коммуникаций, а также Аифференцированного подхода к содержанию информационных потоков. Уровень владения сетевыми ресурсами становится опредемяющей характеристикой эффективности Аеятельности местного уровня власти.

Анализ современных моделей социальнополитических коммуникаций свидетельствует о преобладании сетевого подхода к их осмыслению и оценке. При этом акцентируется внимание на общесоциальной природе информационных коммуникаций, выходящих за пределы отАельных Политических процессов. Политические коммуникации оказываются органической частью социальных коммуникаций, используя отдельные принципы и технологии последних, адаптируя методологические принципы и поАходы к потребностям политической системы и политического процесса ${ }^{19}$. Преимущественное внимание исследователей акцентируется на повышении эффективности использования меха-

Civic Life, by Max McCombs, R. Lance Holbert, Spiro Kiousis, and Wayne Wanta. Cambridge, England: Polity Press, 2011. 272 p.; On Media: Making Sense of Politics, by Doris A. Graber. Boulder, CO: Paradigm Publishers, 2012. - 220 p.

19 Андросова Л.А. Политические коммуникации: монография / Л.А. Андросова, О.Г. Артамонова. - Пенза: Приволжский дом знаний, 2011. - С. 123. низмов политической коммуникации на уровне массового сознания посреАством инструментов Интернет, мобильных технологий, пропаганды и агитации.

ОтАельные эмементы сетевого подхода к осмыслению процессов политической коммуникации появмяются при оценке путей становмения в России развитого гражАанского общества, в частности, посреАством реализации концепций «электронной Аемократии», «электронного правительства» и т.А. Развитие горизонтальных связей межАу избиратемями опосредованное электронными среАствами массовой коммуникации направлено на расширение политического участия гражАан в политических процессах. При этом коммуникативные возможности Аанных информационных технологий оцениваются искАючительно в приклаАном аспекте - Аля повышения политической активности гражАан, в первую очередь, в избирательном процессе. Применение структурно-функционального и системного поАходов к оценке назначения политической коммуникации оказывается недостаточным аля раскрытия ее социально-политического потенциала, как источника формирования общественного мнения, изменения политического сознания и политической культуры гражАанского общества. С нашей точки зрения, политическая и социологическая науки преАложили весьма продуктивный поАхоА к осмыслению коммуникативных процессов в российском обществе через механизмы замены традиционного иерархического взаимодействия пубкичной власти и гражАанского общества партнерскими коммуникациями ${ }^{20}$. Равноправный Аиалог публичной власти и общества, направленный на достижение консенсуса, становится единственно возможным среАством разрешения катентного социально-политического конфликта, обусловленного преобладанием вертикальных коммуникативных каналов. Попытки политической вцасти использовать горизонтальные каналы ограничивались созданием политиче-

\footnotetext{
20 Воробьев Ю.Л. Коммуникативное взаимодействие гражданского общества и структур публичной власти как управленческий процесс: Автореф. дисс... д. социол. н. М., 2008. - С. 10 - 11; Кузьмина А.М. Роль политических коммуникаций в формировании публичной политики: Автореф. дисс...к.полит.н., СПб., 2011. - С. 19.
} 


\section{ПОАИТИКА И ОБЩЕСТВО • 5 (137) • 2016}

ских институтов, реализующих отАельные каналы коммуникации (в частности, деятельность подразделений по связям с общественностью, проведение опросов общественного мнения, развитие отАельных элементов консультативной Аемократии и т.А.). Аиалоговая модель социальных коммуникаций позволяет преодолеть не прямой, транзиторный характер существующих коммуникативных каналов, искмючить неравный Аоступ к информационным ресурсам политических субъектов («knowledge gap effect»). Ее основу Аолжны составить три базовых параметра - Аоверие (ожиАания), понимание (киквиАация коммуникативного барьера) и согласие (смысловая опора общественного сознания), находящиеся в постоянном поиске оптимахьных путей интеграции российского общества ${ }^{21}$.

Механизмы Аиамоговой коммуникации оказались наиболее привлекательными Аля оценки содержания и основных направлений коммуникаций на различных уровнях публичной власти. Связи с общественностью на уровне местной вмасти оцениваются в качестве необходимого условия Аля признания эффективности работы местных политических институтов. Аанное направление Аеятельности местных органов вцасти в течение Алительного периода не признавалось в качестве кмючевого, и приобретало характер ассиметричной (однонаправленной) коммуникации, не вмияя существенно на общественное мнение и общественное восприятие принимаемых и реализуемых политических решений. Изменение требований, предъявмяемых к Аеятельности органов публичной вмасти, их способности использовать современные информационные технологии и сети во взаимоотношениях с гражданским обществом, повышения уровня его политического участия, Аоверия к помитическим решениям, актуамизирует заАачу привлечения потенциала PR службы Амя формирования системы Авухсторонних симметричных коммуникаций ${ }^{22}$. Но попытки анамиза

\footnotetext{
21 Шайхисламов Р.Б. Коммуникативные проблемы социокультурной интеграции современного российского общества: Автореф. дисс...д.социол.н. Уфа, 2007. - С. 20.

22 См. подр.: Вилер К. Организация системы коммуникации в органах местного самоуправления / К. Вилер. О6нинск: Институт муниципального управления, 2002. - 36 с.; Зиятдинова Э.М. Связи с общественностью как инстру-
}

возможных каналов подобной коммуникации, созАания еАиной информационной сети на практике сталкиваются с исключительно институциональной трактовкой перспектив Аанного взаимодействия. Роль и влияние регионального сообщества на процесс выбора каналов сетевой коммуникации ограничивается его включением в уже существующие политические процессы, исключая саму возможность самоорганизации. Зачастую сообщество не включается даже в перечень субъектов помитической коммуникации, ограничиваясь статусом объекта коммуникативных Аействий ${ }^{23}$.

В контексте Аеятемьности органов исполнительной власти субъектов Российской Федерации актуализируется задача оценки механизмов политических коммуникаций, преимущественно однонаправленного характера с эмементами Аиалога власти и гражАанского общества. В рамках приклаАных политологических исслеАований в сфере $\mathrm{PR}$ используются разнообразные конкретно-преАметные методы, позволяющие оценить особенности внешней и внутренней среды регионального политического пространства. Существует значительный пласт методик, связанных с оценкой внутренней среАы органа публичной власти (структурно-функционамьный анализ, системный анамиз и Ар.), внешней среды (SWOT-анализ и Ар.). Но Аля нашего исследования имеет принципиамьное значение оценка используемых региональными органами исполнительной власти каналов политической коммуникации при позиционировании политического института во внешней среде - в отношении СМИ, общественных организаций, политических партий и гражАанского общества. Кроме того, исследование исходит из того, что наиболее системным источником информации о реализуемой стратегии помитического PR непо-

мент взаимодействия субъектов современной российской политики (на примере органов местного самоуправления Республики Татарстан): Автореф. дисс...канд.полит.н. Саратов, 2010. - $22 \mathrm{c}$.

23 Особенно показательны в этом отношении следующие статьи специалистов-практиков: Косова Н. Принципы социальной коммуникации в системе муниципального управления // Власть. 2009. № 9. - С. 34 - 36; Матросова М. В поисках эффективных стратегий политических коммуникаций (на примере Новгородской области) // Власть. 2010. № 12. - C. 29 - 31. 
среАственно выступают СМИ различной политической направленности, взгляАов и воззрений.

В связи с вышеизложенным, нами делается вывоА, о том, что оАной из наиболее репрезентативных методик оценки политического PR на уровне региональной вмасти выступает контент-анализ. Мы попытаемся применить Аанную методику Аля оценки PR деятельности органов государственной власти Омской области (а именно, Правительства Омской области). На территории области преАставлены все виды СМИ - как традиционные (газеты, журналы, радио и телевидение), так и интернет-издания. Значительная часть СМИ явмяются канацами прямого влияния политической власти Губернатора Омской области. Так, самой широкой сетью вещания по области обладает канац «ГТРКОмск», который имеет свои корреспондентские пункты по всей территории региона. Подавцяющее большинство региональных СМИ непосреАственно связано с активной подАержкой «желательных» (позитивно настроенных по отношению к официальной политической власти) СМИ. Реально оппозиционных СМИ в области нет, так как Ааже прокоммунистические изАания системной не критикуют Аеятельность региональной власти.

Подавляющее большинство печатных и эмектронных публикаций затрагивают насущные дела области: безопасность, зАравоохранение, экология, жимищные и коммунальные вопросы. Освещается преимущественно обыденная жизнь и «бытовые» проблемы региона, которые реально интересуют жителей. На основании общей оценки материалов СМИ, в которых критика если и есть, то носит искмючительно бессистемный и поверхностный характер, создается искаженное впечатление о том, что региональная власть справляется с возможенной на нее задачей, поскольку эффективно принимает необходимые политические решений и последовательно выводит регион из социально-экономического кризиса. Аоминирует пафос благополучия региона: рост уровня социально-экономического развития (примеры Аостижения цемей), снижение безработицы, Аемографический подъем и т.А. Упоминания о кризисе (в первую очереАь, Аефицитном бюджете) нивелируется позитивными моментами: открываются новые производства, развивается социокультурная среАа, подАерживается образование и зАравоохранение.

На протяжении преАшествующих десятилетий в СМИ практически отсутствовала критика в аАрес экс-губернатора $\Lambda$.К. Полежаева, и если имели место отдельные негативные факторы, то они сглаживались. Критика была основана не на грубых ошибках, а на мелких неточностях, позволяя констатировать подчеркнуто благоскионное отношение СМИ к губернатору и всей региональной политической власти. Подобная позиция СМИ формировала в общественном сознании положительный образ губернатора, подАерживаемый в прессе Ао тех пор, пока $\Lambda . К$. Полежаев явмялся губернатором. Региональные СМИ активно участвовали в формировании образа губернатора, как чемовека умеющего и способного справиться с мюбой ситуацией. Новый Губернатор В.И. Назаров, по оценке СМИ, управленец, четко и Ааже жестко порой контролирующий ситуацию в области и городе. В качестве оппозиционных СМИ можно отметить такие издания, как «Бизнес-курс», «Ваш Ореом» и «Коммерческие вести». Но фактически это бизнес-издания, рассчитанные на разные категории читатемей.

Правительство Омской области в основном осуществляет политический $\mathrm{PR}$ и рекламу через телевидение и Интернет. Так, самой широкой сетью вещания по области обладает информационный канац «12 канам». Это можно аргументировать тем, что темевидение явмяется наиболее сильным каналом политической коммуникации, который несет не только ту информацию, которая планировацась, но и в большой объем Аополнительной и «лишней» информации. Аля оценки каналов политического PR, используемых Правительством Омской области, нами предпринимается попытка применить прикладной метод контент-анализа, который позволит увидеть в кажущемся однообразии множественную палитру ньюансов и особенностей регионального политического процесса. Согласно позиции $A$. Мангейма и Р. Рича, «контентанализ - систематическая числовая обработка, оценка и интерпретация формы и содержания 


\section{ПОАИТИКА И ОБЩЕСТВО • 5 (137) • 2016}

информационного источника. Контент-анализ снабжает нас методом - вернее, серией метоАов, - с помощью которого мы можем обобщать те или иные материальные проявмения поведения и отношений размичных типов политических субъектов» 24 . Методика включает в себя составление Аиаграмм или подсчет выпадения мибо совпадения частных величин, относящихся к совокупности предопределяемых категорий. Она использовалась, например, в исследовании политического баланса и влияния в среАствах коммуникации посреАством подсчета числа ссымок или распределения эфирного времени межАу политическими партиями, кандиАатами. Контент-анализ относится к неопросным методам, поскольку процесс размещения слов, символов и т.А. в тексте, обеспечивающий коммуникацию с читателем или получателем информации, не зависит от воздействия со стороны исследователя, анализирующего содержание текста ${ }^{25}$. С помощью этого метода исследователь может сравнить содержание множества текстов и анализировать их с помощью количественной методики (например, Аиаграмм, таблиц).

Контент-анализ может документально, с помощью объективных, количественных индикаторов показать, явмяются ли субъективные данные исследователя, основанные на несистематическом наблюдении, истинными. МетоА позвомяет получить воспроизводимые, точные результаты на основании исследования текста. После опредемения единиц анализа и счета исследователь переходит к процедуре подсчета полученных данных. В общем виде она сходна со стандартными приемами классификации по выделенным группировкам. А^я упрощения процедуры применяется составление специальных таблиц, применяются компьютерные программы. Возможно применение и специальных формул, таких как «формула оценки удельного веса смысловых категорий в общем объеме текста», статистических расчетов доходчивости текста, его востребованности Аля читате $\Re^{26}$. В качестве еАиницы анализа исполь-

\footnotetext{
24 Мангейм Д., Рич Р. Политология и методы исследований. - М., 1997. С. 270.

25 Баранов А. В. Опыт текстового анализа газеты // Количественные методы в социальных исследованиях. Инф. бюл. ИКСИ АН СССР. - 1968. - №9. - С. 74.

26 Ядов В.А. Стратегия социологического исследования.
}

зуются категории, объединяющие несколько смежных по содержанию понятий. Именно учет частот встречаемости категорий, а не отАельных слов, позволяет судить о внимании, уделенном в письменном документе тем или иным вопросам, проблемным ситуациям ${ }^{27}$.

При проведении контент-анализа политики PR Правительства Омской области в качестве еАиниц измерения были взяты такие категории как «Правительство», «Министерство», «Губернатор», «Политическое решение», «Аппарат Губернатора», «Создание команды», «Регион», «Политический мидер» и Ар. Периодом поведения контент-анализа стал периоА с мая 2012 по май 2013 гг., когАа в центре внимания регионального политического процесса оказамось назначение и вступление в Аолжность нового Губернатора Омской области - В. Назарова. Аанный процесс сопровожАался кардинальной сменой имиАжа региональной вмасти, формированием «новой команды» и сменой стимя политического управления регионом.

Описание процедуры исследования. Политические коммуникации составмяют кмючевое содержание регионального политического процесса, способствуя вкмючению в него всех политических акторов. ПрежАе всего, акторов, цемевые установки, которых ориентированы на завоевание политической власти - политических партий, групп интересов, политических элит. КажАое политическое объединение, претендующее на определенную степень влияния, на региональную власть, стремится преАставить себя в наилучшем свете в период политических изменений. При этом надо отметить, что образ, преАставление о конкретном акторе в общественном сознании нередко расходится с официально провозгаашаемыми им принципами, а то и вовсе противоречит им. Возник вопрос - посредством каких механизмов раскрывается реальная политическая позиция органа государственной власти (в частности, Правительства Омской области), выраженная в рамках PR стра-

Описание, объяснение, понимание социальной реальности. - М.: «Добросвет», «Книжный дом «Университет», 1998. - C. 37.

27 Lasswell $H$. and associates. The Politically Significant Content of the Press: Coding Procedures // Journalism Quarterly. - March 1942. - Vol. 19. - №. 1. - P. 32. 
тегии, реализуемой подразделением по связям с общественностью? Возможно, ответ на этот вопрос может быть получен на основе оценки характера репрезентации официальной и неофициальной позиции СМИ в периоА вступмения и нахождения в Аолжности В. Назарова, отношения к процессу Аругих региональных поАитических акторов. Характер отношения можно определить с помощью анализа содержания материалов, распространяемых через среАства массовой коммуникации. Сопоставмяя публикации в печатных СМИ (в качестве источников были избраны региональные издания: «Омская правда », «Ваш Ореол» и «Омский вестник» за период с 4 мая 2012 г. по 6 мая 2013 г.) мы покучим возможность определить, какова степень отклонения, тактической позиции официального подразделения по связям с общественностью, выраженной в конкретных выступлениях, позициях, мнениях, от его официальной «стратегической» позиции. Такое сравнение дает нам возможность оценивать последовательность помитических решений органа публичной власти или, наоборот, его бессистемности.

В качестве прикладного метода обработки информации нами быма избрана программа TextAnalyst ${ }^{28}$. Аанная программа обладает слеАующими возможностями: структурный анализ содержания текста, реферирование, формирование гипертекста, смысловой поиск ${ }^{29}$. КажАая еАиница анализа рассматривается по трехбальной шкаме в зависимости от частоты и контекста ее упоминания: положительный $(+)$ контекст употребления Аанной единицы анализа, нейтральный (0) или же негативный (-). На основе контекста употребления и частоты употребления можно будет реконструировать PR стратегию Губернатора и Правительства Омской обмасти, позиционированием которой занимается ГАавное управление по декам печати, темерадиовещания и среАств массовой коммуникации. Таблицы отношений помещены в приможении №2.

При помощи методики контент-анализа, описанной выше, удалось провести исследова-

\footnotetext{
28 НПИЦ «МикроСистемы» [Электронный ресурс] // [Режим доступа]:URL:http: //www. analyst. ru (Дата обращения: 03.08.2013)

29 Чураков А. Н. Компъютерный контент-анализ. М.: Институт социологии РАН, 1996. - С.196.
}

ние частоты упоминания в трех региональных общественно-политических газетах «Омская правда », «Омский вестник» и «Ваш Ореол» ключевых атрибутов нового этапа регионального политического процесса - «Правительство», «Министерство», «Губернатор», «Политическое решение», «Аппарат Губернатора», «СозАание команды», «Регион», «Президент», «Кредит Аоверия», «Смена власти». Результаты анализа оказались достаточно показательными. Первое, на что пришлось обратить внимание, было то, что практически во всех информационных сообщениях отсутствуют единицы анализа, относящиеся к международным отношениям и месту Омской обкасти в межАународных и трансграничных процессах. Исключение составмяет лишь «Ваш Ореол», чья позиция отличается большей критической направленностью по отношению к новому Губернатору.

Позиция регионального правительства в отношении сферы образования сосредотачивается вокруг таких стандартных Амя СМИ позиций как равенство стартовых возможностей, реформа образования, постепенное расширение платных форм образовательных услуг и т.А. Все 16 упоминаний политики Правительства в сфере образования положительны. То же самое относится и к научной и культурной сферам (из 47 упоминаний - все положительные) - развитие научной и социокультурной деятельности. Что касается социальной политики, то зАесь большое внимание уделяется пенсиям (47 положительных упоминаний из 52). Пианируется проведение пенсионной реформы, предполагающее конкурирование государственных и негосударственных пенсионных фондов, переход на распоряАительно-накопительную пенсионную систему. Предлагается отмена ряда Аьгот преАставитемей экономической эмиты, в хозяйственной жизни, мьгот, установленных без учета нужАаемости (44 отрицательных упоминаний из 46). СреАи форм государственного устройства - явна скмонность к укреплению федералистских отношений (42 положительных, 45 нейтральных упоминаний). Аля газеты «Ваш Ореол» свойственна критика Аействий как преАшествующего, так и нынешнего состава Правительства Омской области (ни оАного положительного упоминания: 51 ней- 


\section{ПОАИТИКА И ОБЩЕСТВО • 5 (137) • 2016}

тральных и 12 отрицательных). При этом отме-

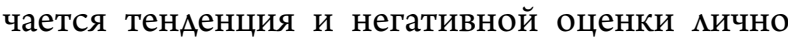
Губернатора (25 негативных упоминаний, 22 нейтральных и 42 положительных).

В области общеполитических вопросов илеал связывается с созданием правового государства, с минимальным вмешательством в экономику, симьной и независимой судебной властью, минимальным количеством мьгот (государство заботиться только о тех, кто не в состоянии позаботиться о себе сам) - $16 \ll 3 а », 32 \ll$ нейтрамьно», 13 «против». Значительное внимание в публикациях отводится аграрной стратегии нового Правительства или семьскохозяйственному сектору (всего 23 упоминания, 23 положительных). Например, газета «Ваш Ореом» отмичается оппозиционным характером и реализует критическую стратегию по отношению ко всем инициативам органов вмасти. Оценка экономической программы Правительства Омской обмасти в Аанной газете существенно отмичается от Аругих и содержит в себе ряА интересных моментов, подчеркивающих и партийную принаАмежность СМИ. Так, например, констатируется очевидность перехода от государственной собственности к Аругим видам (государственная собственность - 2 упоминания, из них 1 со знаком +; нейтрахьное отношение к частной собственности - 2 упоминания, оАно положительное, Аругое отрицательное; общественная собственность - из 9 упоминаний 4 положительных, 1 отрицательное, 4 нейтральных). Наблюдается также больший акцент на поАнятии семьского хозяйства, освещении жизни села и Аеревни (из 9 упоминаний 7 положитемьных). При этом промышленность встречается только 5 раз (4 в поможительном аспекте). ОАин раз говорится о необходимости инвестирования в отечественное производство. Необходимым также считается проведение налоговой реформы, ужесточение налоговых сборов с граждан, имеющих «сверхвысокие Аоходы». В газете в среАнем в кажАом номере встречается положительное упоминание государства (15 нейтральных и одно отрицательное), часто проходит идея о борьбе за национально-государственные интересы. Немалая ромь отводится регионацьным органам исполнительной власти (5 положитемьных упоминаний из 6) - обеспечение безопасности, защита прав гражАан и т.А. Большое внимание уделяется помитике Правительства Омской области в сфере науки, образования, развития культуры. В целом газета «Ваш Ореол» ориентирована преимущественно только на оценку внутренних проблем (помное отсутствие внешнеполитических залач, цемей), стоящих переА новым региональным руководством.

Результатом проведенного анациза стало воспроизводство так называемой «семантической шкалы». Развитием семантического Аифференциала в области контент-анализа явилась семантическая шкала, которую обычно опрелемяют как алгоритм, с помощью которого осуществляется измерение в тех случаях, когАа оно является отображением изучаемых объектов в числовую математическую систему ${ }^{30}$. C помощью семантической шкалы каждому понятию ставится определенное число знаков, называемое шкальным значением объекта. Примерами семантических шкал, ориентированных на моделирование политической реальности, могут служить пятибамльные шкалы политической ориентации $\ll \Lambda е-$ вые(1) - мевоцентристы(2) - центристы(3) правоцентристы (4) - правые $(5)^{31}$. Понятно, что эти шкалы могут служить измерительными инструментами в ходе экспертной оценки политической ориентации высказываний политических Аеятелей, а также политической стратегии всего органа публичной власти. Использование в ходе моделирования Авух или нескольких семантических шкал позволяет создать семантическое пространство. Семантическое шкама ими пространство, преАставмяют собой систему признаков, описаний объектной и социамьной Аействитемьности, определенным образом структурированных. При геометрическом преАставлении семантического пространства значение отображается соответственно как точка оси ики как вектор с заданными координатами внутри n-мерного

\footnotetext{
30 Мангейм Д., Рич Р. Анализ общественной политики и оценка программ // Политические исследования. - 1991. № 3. - С. 37.

31 Тимохина А. А. Контент - анализ как метод исследования средств массовой информации (на примере исследования рекламы лекарственных средств) [Электронный ресурс] // [Режим доступа]: URL: http: //www. glasnet. $\mathrm{ru} /$ asch/sociology/questions/quest48html (Дата обращения: 03.08.2013)
} 
пространства, координатными осями которого выступают выдеменные категории-факторы ${ }^{32}$.

Амя того чтобы оценить эффективность PR, реализуемом региональным Правительством, нам необходимо воспроизвести следующую шкаку: «Аоверие к региональному правительству Нейтральная позиция - Недоверие к регионамьному правительству». Поскольку цель политики PR - сформировать и подАерживать положительный имиАж публичной власти в глазах общества, поэтому от того «образа вмасти», который созАают СМИ, напрямую зависит и ее восприятие населением региона. Из схемы видно, что чем Аальше отходить от центра влево, тем становится очевидным эффективность PR стратегии, избранной Правительством Омской области.

Подсчет положительных и отрицательных оценок заданных параметров приводит к следующим результатам. Газета «Омский вестник» показала наибольшее количество положительных оценок практически всех направлений политики Правительства Омской области (за исключением социального) - 48 против 10, набрав в общей сложности коэффициент 4,5 (+), что свидетельствует о высокой степени доверия Аанного СМИ к новому составу Правительства и мично к Губернатору Омской области. Прогубернаторский характер отмечается в «Омском вестнике» с 2011 г. после прекращения противостояния Мэра города Омска и Губернатора Омской области.

«Омская правда» всегАа явмялась газетой про правительственной, поэтому сложно бымо рассчитывать на Аругие результаты. Количество положительных оценок составило 52, отрицательных 8. В целом, газета позиционирует себя по отношению к региональной исполнительной власти с искмючительно позитивных позиций. В тоже время, отмечается настойчивая резкость (иногАа в форме увещаний) в отношении социального блока политики региональной власти, что свидетельствует о стремлении завоевать нового читатемя и стать «ближе» к нужАам гражАан Омской области.

Наконец, наиболее интересные результаты продемонстрироваяа газета «Ваш Ореол». Со-

\footnotetext{
32 Грачев М.Н. Политика, политическая система, политическая коммуникация. - М.: НОУ МЭЛИ, 1999. - С. 79.
}

храняя образ оппозиционной газеты по отношению к региональной и муниципальной вмасти, она существенно трансформироваца свое отношение к новому Губернатору и Правительству. Негативные оценки сохранились практически во всех блоках внутренней и внешней политики региона, но ответственность за неудачи возмагамась на преАшествующее руководство Омской области во главе с Губернатором $\Lambda$.К. Полежаевым. Напротив, подавмяющее большинство оценок носили позитивный или нейтральный характер, когАа речь заходила о перспективах нового политического руководства (47 против 25). ПоАобную ситуацию можно интерпретировать как результат последовательной работы ГАавного управления по делам печати, телерадиовещания и среАств массовой коммуникации по формированию положительного имиАжа власти в глазах общественности, а также ожидаемостью смены политического руководства в глазах граждан и возможением достаточно больших надежА на новое «молодое» и «активное» политическое руководство региона. В целом, «Ваш Ореол» можно отнести к СМИ стремящемуся к формированию общественного Аоверия к вмасти, но сохраняющему нейтральную позицию, без резких высказываний и навязывания негативного отношения обществу.

Aмя оценки PR политики, реализуемой органами государственной власти Омской области, необходимо соотнести покученные результаты контент-анализа и реальную практику формирования бцагоприятного имиАжа вмасти и АОАжностных миц. Последняя становится результатом анализа официальных материалов ГАавного управления по Аелам печати, темерадиовещания и среАств массовой коммуникации Правительства Омской области за период 2012 - 2013 гг., которые содержат кмючевые направления политики $\mathrm{PR}^{33}$. Возможно, выделить пять каналов коммуникации, используемых Управлением. Вопервых, установление, подАержание, расширение контактов с гражданами и организациями посреаством институциональных форм (бри-

\footnotetext{
33 [Электронный ресурс] // [Режим доступа]:http://guptr. omskportal.ru/ru/RegionalPublicAuthorities/executivelist/ GUPTR/Zadachi_Funkzii/Sektor.html (Дата обращения: 13.09.2013)
} 
финги, пресс-конференции, встречи с Аолжностными кицами, конференции, круглые столы, обращения граждан и т.А.). Во-вторых, информирование общественности о существе принимаемых политических решений посреАством СМИ. В-третьих, мониторинг общественной реакции на Аействия Аолжностных миц и органов власти. В-четвертых, прогнозирование социально-политического процесса, обеспечение органов вмасти прогнозными аналитическими разработками. В-пятых, формирование благоприятного имиАжа власти и Аолжностных Аиц.

Процессы помитической коммуникации приобретают свойство кАючевого источника и свойства политического пространства на различных уровнях публичной власти. Сетевой характер послеАних созАает необходимые условия Аля согласования интересов и потребностей кмючевых субъектов политического процесса посреАством их агрегирования и артикукяции общественными объединениями, органами публичной власти в политические требования к системе. Политические инициативы и проявления активности местного сообщества становятся необхоАимым элементом процесса самоорганизации только при условии использования политическими субъектами всего разнообразия сетевых коммуникаций (горизонтальных, вертикамьных и Аиагональных). Политический коммуникативный потенциац местной вцасти выражается в Аостаточном уровне компетенции ключевых субъектов, способных не только включаться в сетевое поле взаимодействия, но и определять его структуру во времени и пространстве. Общественным объеАинениям принаАлежит кмючевая роль в процессе формирования и использования размичных коммуникативных средств и механизмов.

Таким образом, стоит отметить, что Правительство Омской области Аля политических PR и рекламы активно и умело, использует всевозможные традиционные и новые средства массовой информации и коммуникации, что позволяет сАелать их Аостаточно популярными и Аейственными. Образ политических Аеятемей и государственных структур освещается в основном в печатных изАаниях, на телевидении и в интернете. Причем в послеАнее время печат- ные СМИ уступают свое место электронным изАаниям и можно констатировать, что за небольшой периоА времени они могут практически полностью вытеснить из рынка политической рекламы. Аругие $\mathrm{PR}$ технологии в Омской области используются слабо и неэффективно.

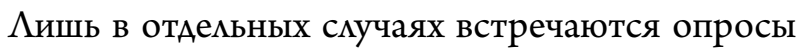
жителей, рекламные акции, нагляАная агитация, объявления, видеоклипы, споты, видеофильмы. Практически отсутствует наружная политическая реклама - брандмауэры, световая реклама, мозунги, транспаранты и т.А.

Использование семантических инструментов контент-анализа, информации среАств массовой коммуникации позволяет не только оценить эффективность работы подразделений по связям с общественностью, но и явцяется важным инструментом стратегического планирования регионацьного политического процесса, позволяющего получить важную информацию, необходимую Аля распределения материальных и мюАских ресурсов, определения событийного ряда, создания меАиа-планов, разработки информационной и рекламной кампаний. Анакиз материалов, регулярно выходящих в эфир, Аает возможность увидеть, какую информационную политику осуществляет тот или иной политический актор ики институт, какие тематические подборки преобладают в ежеАневной информации, каких явно не хватает; какую политическую (культурную) картину формирует определенная организация, компания, группа, партия и проч. Аля своей аудитории; обеспечивается ки реальный плюрализм или же преобладает монополизм оАних и тех же социамьных групп. Что отмичает оАин информационный канац от Аругого, какие информационные источники использует кажАый из них, чем отличается тематика конкурентов, что в ней схожего, что именно можно бымо бы изменить, позаимствовать ики привнести все эти и многие Аругие задачи можно ставить и решать, используя метоА социологического анамиза текстов, метод контент-анациза.

Используемые каналы политической коммуникации представмяются недостаточными, поскольку свидетельствуют не о стратегическом, a о мобилизационном характере политики PR, реализуемой органами государственной вмасти 
Омской области. Аиамоговый характер коммуникации требует включения в государственное управление в качестве равноправных партнеров ряда политических акторов, предполагает процессы взаимной коммуникации, истинного Аиалога, совместно выработанной Аоговоренности. Аиалог означает, что региональное правительство не просто Аоводит до гражАан, их объеАинений уже выработанные решения и программы, добиваясь затем их подАержки, а привлекает объединения и граждан к участию в самом процессе выработки и принятия решений.
Причем, инициатором Аиалога не обязательно выступает правительство. Только в условиях равноправного Аиалога может иАти речь о сетевой структуре политического PR. Взаимодействия властных и общественных структур в процессах государственного управления, решения тех или иных конкретных задач, возможно, только на основе доверия, возникающего до и в процессе совместной Аеятельности межАу этими структурами, что в свою очередь преАполагает открытость властных структур переА гражданами и их объединениями.

\section{БИБАИОГРАФИЯ}

1. Андросова $\Lambda$.А. Политические коммуникации: монография / А.А. Андросова, О.Г. Артамонова. - Пенза: Приволжский дом знаний, 2011. - 156 с.

2. Баранов А. В. Опыт текстового анализа газеты // Количественные методы в социальных исследованиях. Инф. бюл. ИКСИ АН СССР. - 1968.-№9.

3. Вимер К. Организация системы коммуникации в органах местного самоуправления / К. Вимер. Обнинск: Институт муниципального управления, 2002. - 36 с.

4. Воробьев Ю.А. Коммуникативное взаимодействие гражАанского общества и структур публичной власти как управленческий процесс: Автореф. Аисс. Аокт. социол. н. М., 2008. - 37 с.

5. Грачев М.Н. Политическая коммуникация: теоретико-методологический анализ: Автореф. Аисс. докт. полит.н. М.: МГПУ, 2005. -328 с.

6. Грачев М.Н. Политическая коммуникация: теоретические концепции, модели, векторы развития: Монография / М.Н. Грачев. - М.: Прометей, 2004. - 360 с.

7. Грачев М.Н. Политика, политическая система, политическая коммуникация: Монография. - М.: НОУ МЭАИ, 1999. - $168 \mathrm{c.}$

8. Зиятдинова Э.М. Связи с общественностью как инструмент взаимодействия субъектов современной российской политики (на примере органов местного самоуправления Республики Татарстан): Автореф. Аисс... канА.полит.н. Саратов, 2010. - 22 с.

9. Косова Н. Принципы социальной коммуникации в системе муниципального управления // ВАасть. 2009. № 9. - С. $34-36$.

10. Кривокора Е.И. Коммуникационные источники организационного развития / Е.И. Кривокора // Проблемы современной экономики. - № 3. - 2008. - С. 313 - 317.

11. Кузьмина А.М. Роль политических коммуникаций в формировании публичной политики: Автореф. Аисс... к.помит.н., СПб., 2011. - 26 с.

12. Ауман Н. ВАасть / Н. Ауман / Пер. с нем. А.Ю. Антоновского. М.: Праксис, 2001. - 256 с.

13. Ауман Н. Невероятность коммуникации / Н. Ауман // Пробцемы теоретической социомогии / РеА. А.О. Бороноев. Вып. 3. СПб.: ИзА-во СПбГУ, 2000.

14. Мангейм А., Рич Р. Анализ общественной политики и оценка программ // Политические исследования. 1991.-№ 3. - С. 30 - 41.

15. Матросова М. В поисках эффективных стратегий политических коммуникаций (на примере НовгороАской области) // Внасть. 2010. № 12. - С. 29 - 31.

16. Назарчук А.В. Теоретико-поэтические воззрения Никласа Аумана / А.В. Назарчук // Полис. - 2006. № 3.

17. Сморгунов А.В. Сети, знания, коммуникация / А.В. Сморгунов // Аемократия и управмение: Информационный бюмметень исследовательского комитета РАПН по сравнительной политологии (СП-РАПН). СПб: РАПН, 2006. - С. 5 - 14.

18. Тимохина А. А. Контент-анализ как метоА исследования среАств массовой информации (на примере исследования рекламы мекарственных среАств) [Электронный ресурс] // [Режим Аоступа]: URL: http: // www. glasnet. ru/ asch/sociology/questions/quest48html (Аата обращения: 03.08.2013) 


\section{ПОАИТИКА И ОБЩЕСТВО • 5 (137) • 2016}

19. Тоффмер Э. Метаморфозы власти / Пер. с анг. / Э. Тоффмер. - М.: ООО «ИзА-во АСТ», 2003. - 669 с.

20. Хабермас Ю. Моральное сознание и коммуникативное действие / Ю. Хабермас. СПб.: Наука, 2001. - 377 с.

21. Хабермас Ю. Отношение к миру и рациональные аспекты действия в четырех социологических понятиях действия / Ю. Хабермас / Пер. с нем. Т. Тягуновой // Социологическое обозрение. - 2008. - Т. 7. № $1 .-$ C. $3-25$.

22. Хакен Г. Информация и самоорганизация: Макроскопический поАхоА к сложным системам / Г. Хакен. М.: «Мир», 1991. - 240 с.

23. Чураков А. Н. Компъютерный контент-анализ. М.: Институт социологии РАН, 1996.

24. Шайхисламов Р.Б. Коммуникативные проблемы социокультурной интеграции современного российского общества: Автореф. Аисс... А.социол.н. Уфа, 2007. - 37с.

25. ЯАов В.А. Стратегия социологического исследования. Описание, объяснение, понимание социальной реальности. - М.: «Аобросвет», «Книжный дом «Университет», 1998.

26. Habermas J. What is universal pragmatics? / Communication and the evolution of society. N.Y.: Polity Press, 1984. - P. 1 - 68.

27. Lasswell H. Propaganda technique in the World War. London, 1927.

28. Schramm W. The nature of communications between humans. Urbana, 1972.

29. Making Sense of Media \& Politics: Five Principles in Political Communication, by Gadi Wolfsfeld. New York: Routledge, 2011. - 160 p.

30. On Media: Making Sense of Politics, by Doris A. Graber. Boulder, CO: Paradigm Publishers, 2012. - 220 p.

31. The News and Public Opinion: Media Effects on Civic Life, by Max McCombs, R. Lance Holbert, Spiro Kiousis, and Wayne Wanta. Cambridge, England: Polity Press, 2011. - 272 p.

32. Voltmer K. Mass Media \& New Democracies. Routledge, 2012. - 240 p.

33. НПИЦ «МикроСистемы» [Эмектронный ресурс] // [Режим Аоступа]:URL:http: //www. analyst. ru (Аата обращения: 03.08.2013)

\section{REFERENCES (TRANSLITERATED)}

1. Androsova L.A. Politicheskie kommunikatsii: monografiya / L.A. Androsova, O.G. Artamonova. - Penza: Privolzhskii dom znanii, 2011. - 156 s.

2. Baranov A. V. Opyt tekstovogo analiza gazety // Kolichestvennye metody v sotsial'nykh issledovaniyakh. Inf. byul. IKSI AN SSSR. - 1968.-№9.

3. Viler K. Organizatsiya sistemy kommunikatsii v organakh mestnogo samoupravleniya / K. Viler. Obninsk: Institut munitsipal'nogo upravleniya, 2002. - $36 \mathrm{~s}$.

4. Vorob'ev Yu.L. Kommunikativnoe vzaimodeistvie grazhdanskogo obshchestva i struktur publichnoi vlasti kak upravlencheskii protsess: Avtoref. diss. dokt. sotsiol. n. M., 2008. - 37 s.

5. Grachev M.N. Politicheskaya kommunikatsiya: teoretiko-metodologicheskii analiz: Avtoref. diss. dokt. polit.n. M.: MGPU, 2005. - 328 s.

6. Grachev M.N. Politicheskaya kommunikatsiya: teoreticheskie kontseptsii, modeli, vektory razvitiya: Monografiya / M.N. Grachev. - M.: Prometei, 2004. - 360 s.

7. Grachev M.N. Politika, politicheskaya sistema, politicheskaya kommunikatsiya: Monografiya. - M.: NOU MELI, 1999. - $168 \mathrm{~s}$.

8. Ziyatdinova E.M. Svyazi s obshchestvennost'yu kak instrument vzaimodeistviya sub"ektov sovremennoi rossiiskoi politiki (na primere organov mestnogo samoupravleniya Respubliki Tatarstan): Avtoref. diss ... kand. polit.n. Saratov, 2010. - 22 s.

9. Kosova N. Printsipy sotsial'noi kommunikatsii v sisteme munitsipal'nogo upravleniya // Vlast'. 2009. № 9. S. $34-36$.

10. Krivokora E.I. Kommunikatsionnye istochniki organizatsionnogo razvitiya / E.I. Krivokora // Problemy sovremennoi ekonomiki. - № 3. - 2008. - S. 313 - 317.

11. Kuz'mina A.M. Rol' politicheskikh kommunikatsii v formirovanii publichnoi politiki: Avtoref. diss ...k.polit.n., SPb., 2011. - $26 \mathrm{~s}$.

12. Luman N. Vlast' / N. Luman / Per. s nem. A.Yu. Antonovskogo. M.: Praksis, 2001. - 256 s.

13. Luman N. Neveroyatnost' kommunikatsii / N. Luman // Problemy teoreticheskoi sotsiologii / Red. A.O. Boronoev. Vyp. 3. SPb.: Izd-vo SPbGU, 2000.

14. Mangeim D., Rich R. Analiz obshchestvennoi politiki i otsenka programm // Politicheskie issledovaniya. 1991.-№ 3. - S. $30-41$. 


\section{ПОАИТИЧЕСКИЕ КОММУНИКАЦИИ}

15. Matrosova M. V poiskakh effektivnykh strategii politicheskikh kommunikatsii (na primere Novgorodskoi oblasti) // Vlast'. 2010. № 12. - S. 29 - 31.

16. Nazarchuk A.V. Teoretiko-poeticheskie vozzreniya Niklasa Lumana / A.V. Nazarchuk // Polis. - 2006. - № 3.

17. Smorgunov L.V. Seti, znaniya, kommunikatsiya / L.V. Smorgunov // Demokratiya i upravlenie: Informatsionnyi byulleten' issledovatel'skogo komiteta RAPN po sravnitel'noi politologii (SP-RAPN). - SPb: RAPN, 2006. S. $5-14$.

18. Timokhina A.A. Kontent-analiz kak metod issledovaniya sredstv massovoi informatsii (na primere issledovaniya reklamy lekarstvennykh sredstv) [Elektronnyi resurs] // [Rezhim dostupa]: URL: http: //www. glasnet. $\mathrm{ru} / \sim$ asch/sociology/questions/quest48html (Data obrashcheniya: 03.08.2013)

19. Toffler E. Metamorfozy vlasti / Per. s ang. / E. Toffler. - M.: OOO «Izd-vo AST», 2003. - 669 s.

20. Khabermas Yu. Moral'noe soznanie i kommunikativnoe deistvie / Yu. Khabermas. SPb.: Nauka, 2001. - 377 s.

21. Khabermas Yu. Otnoshenie $k$ miru i ratsional'nye aspekty deistviya $v$ chetyrekh sotsiologicheskikh ponyatiyakh deistviya / Yu. Khabermas / Per. s nem. T. Tyagunovoi // Sotsiologicheskoe obozrenie. - 2008. - T. 7. - № 1. S. $3-25$.

22. Khaken G. Informatsiya i samoorganizatsiya: Makroskopicheskii podkhod k slozhnym sistemam / G. Khaken. M.: «Mir», 1991. $-240 \mathrm{~s}$.

23. Churakov A. N. Komp"yuternyi kontent-analiz. M.: Institut sotsiologii RAN, 1996.

24. Shaikhislamov R.B. Kommunikativnye problemy sotsiokul'turnoi integratsii sovremennogo rossiiskogo obshchestva: Avtoref. diss ... d.sotsiol.n. Ufa, 2007. - 37s.

25. Yadov V.A. Strategiya sotsiologicheskogo issledovaniya. Opisanie, ob"yasnenie, ponimanie sotsial'noi real'nosti. M.: «Dobrosvet», «Knizhnyi dom «Universitet», 1998.

26. Habermas J. What is universal pragmatics? // Communication and the evolution of society. N.Y.: Polity Press, 1984. - P. $1-68$.

27. Lasswell H. Propaganda technique in the World War. London, 1927.

28. Schramm W. The nature of communications between humans. Urbana, 1972.

29. Making Sense of Media \& Politics: Five Principles in Political Communication, by Gadi Wolfsfeld. New York: Routledge, 2011. - $160 \mathrm{p}$.

30. On Media: Making Sense of Politics, by Doris A. Graber. Boulder, CO: Paradigm Publishers, 2012. -220 p.

31. The News and Public Opinion: Media Effects on Civic Life, by Max McCombs, R. Lance Holbert, Spiro Kiousis, and Wayne Wanta. Cambridge, England: Polity Press, 2011. - 272 p.

32. Voltmer K. Mass Media \& New Democracies. Routledge, 2012. - $240 \mathrm{r}$.

33. NPITs «MikroSistemy» [Elektronnyi resurs] // [Rezhim dostupa]:URL:http: //www. analyst. ru (Data obrashcheniya: 03.08.2013) 